\title{
Dynamics of Gender Self and Other in Sharon Doubiago's South America Mi Hija
}

Received: May 09, 2020

doi: I0.4628I/aijssr.v5i3.602

\author{
Abdullah H. Kurraz \\ Al-Azhar University-Gaza, Palestine \\ E-mail: abdhk99@yahoo.com
}

Accepted: May 30, 2020

Online Published: June 09, 2020

URL: https://doi.org/I0.4628I/aijssr.v5i3.602

\begin{abstract}
This paper explores the poetic feminist discourse of the South American poet Sharon Doubiago's epic South America Mi Hija and how she engenders and maintains her gender's visions and beliefs in masculine societies that still engulf the whole human world. She poetically defends herself and her gender refusing to submit to the standing patriarchal paradigm. She portrays herself as a modern spokesperson of her gender and its vulnerability to victimization. Doubiago also tries to cast her challenge against the dominant patriarchal power. Further, this paper sheds light on the poet's optimism in winning the battle in the light of modern feminist analysis, providing relevant representations of her poetic discourse. It elucidates how the poet publicizes her feminist and gender thoughts despite the domination of the masculine power. As a result, as an intimate feminist poet, Doubiago succeeds in identification with her psyche and other similar selves that can assimilate with her soul and vision. In a broader sense, the focal hypothesis of this paper revolves around conceptualizing feminist poetics and gender in an appreciative receptionist way.
\end{abstract}

Keywords: Feminism, Victimization, Masculinity, Feminist Discourse, Otherness.

Sharon Doubiago engenders a powerful exploration of the mother-daughter relationship, deriving from the Demeter and Persephone myth. Also, she engages in a related feminist discourse exploring man-woman relationships relying on her own understanding of female/feminine, as the self, and male/masculine, as the other. There are three main tracks that feminism works on: the critique of the established views of the self, the reclamation" of women's selfhood, and the "reconceptualization" of the self to incorporate women's experiences (Meyers, 2000). Doubiago masters such feminine knowledge and manifests it in South America Mi Hija (1992). Julie Ellison (1990) regards the gendered self as the "locus of conversation among the many languages" of the mind and of the society, such as divination, desire, family, friendship, politics, and economy (p. 223). Alicia Ostriker (200I) describes Doubiago's South America Mi Hija as "global in reach, formally experimental," for it foregrounds for a sincere experimental travel feminist discourse suitable to be a guide to every woman everywhere in our globe (p. 257).

Besides, Irving Howe (1992) emphasizes the importance of the self in studying literature, since the self implies "an acceptance of the sufficiency of the human condition so that divinities, myths, and miracles slip into obsolescence" (p. 252). It is a universal discourse that enables the poetess to go deep into the momentum of female-male exchange and mutual feelings and perspectives towards each other.

Doubiago is aware of the two basic human types, male and female, thus, the way the relationship between women and men is structured is a "basic model for human relations" (Eisler, I987, p.I68). Moreover, Jeanne Hong Zhang (2004) comments on women's poetry in the light of the twentieth century new critical schools saying that any feminist-based poetry is constituted by "female-authored poems that deal with gender-based themes, experience and psychology in a distinctive language usage" (p. I6).

In South America Mi Hija, Doubiago travels with her daughter to Colombia, Peru, and Ecuador so that she can address herself, the other, and her daughter. We read the poet's sufferings during such a journey where she and her daughter encounter thieves, beggars, and deviated people. Both of them visit different places and ruins where there are manifestations of a long history of human sacrifice, conquest, and revolution. The poet aspires to deeply and freely communicate with the self and the other and debate about "gender war." It is traditional to blame "hormones" for the inability to communicate with the same gender in any 
society. In this sense, M. Lewis and J. Brooks-Gunn (I989) define gender as the "single most salient individual variable in the socialization process" that affects how people think of themselves and how others respond to them. In addition, both writers emphasize the role of language in the construction of the self, viewing language as a "discursive action" (p. I62).

Furthermore, Doubiago experiences a lot of historical places and different people where she is influenced by what she sees and then delivers this lengthy poem, all of which sustains her self-knowledge and self-discovery. In this sense, Doubiago's poetic discourse is the "medium for the commonality of thought" that allows the readers to understand the "feminine knowledge" in social and textual affairs (Ellison, 1990, p. 88). The poet mentions a lot of goddesses' names and mythical figures, such as Isis, Ishtar, Europa, Demeter, and Persephone. These mythical names are masterfully employed by the poet to signify a variety of themes and issues such as gender relations and tensions, familial and social ties, seduction, betrayal, birth, death, nature, and femininity. Her landscape seems to be cosmopolitan without time to serve as a "point of departure" for most of her poems in this volume (Ullman, I993, p. I89). This collection of poems is enriched with names, facts places, quotes, and symbols, all of which serve as a powerful source for Doubiago's knowledge and to sustain her vision as a female figure. In addition, Doubiago testifies in a plain language that man carries "both/the male and the female/ in his genital sacks" (I992, p. 27I). Whereas woman, our other first, carries ova, then a fetus in the uterus, then a child at her breasts. This testament allows the poetess to reflect her interior identity, as female, derived from women's "biological nature," which is manifest in the "genitalia" (Meyers, 2000). Catherine R Stimpson (I993) points to the poet's poetics in privileging heterosexuality that is changed with "archaism and nostalgia," to redeem the sexualities of the "grubby, steely, killing" women in the process of regenerating life cycle (p. 264). In this sense, Doubiago mythologizes sexuality, as it is a wide appeal across a modem spectrum of today's ideologies. Accordingly, the poet seems conscious of the differences among women, too. Her consciousness is shown clearly, when she travels through "Third World" countries, where women cannot escape the gaps among woman that class, race, and culture have established.

Throughout this personal travel biography, Doubiago expresses her feelings towards the conflicting positions between the male and female, extending this discourse to include the conflicting relationships between mother and daughter, nation and nation, man and nature, man and woman, and the self and the other. Doubiago's feminist discourse emphasizes crucial features of selfhood such as "inter-subjectivity, heterogeneity, and social construction" (Meyers, 2000). Besides, she adopts a powerful didactic discourse in an attempt to convey a clear message to her audience about such issues. In this sense, Doris Lynch (2000) implies that Doubiago has the strong intention to present "a vital, feminist, and extremely sensitive self," which South America Mi Hija keeps showing in an aesthetic and influential way (p. 277). Zhang maintains that such feminist writings are similar to a "web of interrelated metaphors from graveyards to snow, scissors to paradoxical images of motherhood and life itself," and this technique is employed by Doubiago in most of her poems in South America Mi Hija (2004, p. I62).

Doubiago is fully aware of the tenderness and vulnerability of her daughter and her innocence as well. Accordingly, she tries to answer her daughter's question "what is a Virgin?" in a careful and responsible way:

\author{
But here at culture's altar \\ where she \\ is buried alive \\ here where she is forever veiled from the world \\ that dies for need of Her \\ here, where all the past uses of that word \\ Virgin \\ fall on her as stone \\ though I defined it without judgment or anger \\ my daughter, $\mathrm{O}$ Virgin undone \\ understands \\ Are there any good men, Mom? (I992, p. I89)
}

Here, this stanza reminds me of an ancient habit, where the fathers, before the dawn of our religions, used to bury their female infants alive. They claimed that females were the source of shame to their fathers. Yet, who is responsible for these cultural and social habits? Is it the imperfect familial raising? I think it is something behind the poet's control that she cannot tell or decide. Then the word "virgin" falls like a stone on the poetess's daughter's head because she does not know what a "virgin" is or what the society's attitude towards virgins is in such a modem world. The last three lines of the previous quote work as a didactic discourse to tell us readers that mothers are the advocate of their virgin daughters, and they should defend their innocence, chastity, femininity, and virginity as well. The last question resonates with the main question that the daughter raises and opens into subquestions regarding cultural, religious, social, and political perspectives towards female position in society. Women and men feel in the same way "they need exercise for their faculties and a field for their efforts," argues Virginia Woolf (I989), she adds that women are victims of religious, cultural and social rigid restraints and maltreatments (p. IOI). Doubiago maintains and practices her creative faculties despite such constraints. 
Doubiago's poetic journey allows us to explore her strong feelings such as her grief and compassion for the man whom she lost. This event is a tragic one in the poet's life and intensifies her worry and grief. Ullman regards such an event as an opening into another major themes such as the yearning men and women have for one another and the impossibility of "satisfying that yearning" (I993, p. I9I). The theme is manifested in the poet's response to her daughter:

\author{
Nothing will appease her fury and \\ her three day-and-night orgy \\ of crying, her grief \\ for being born (1992, p. I25)
}

This situation reflects the daughter's identification with her mother's psyche in lamenting the loss of her man. This signifies the common gender quality they share with each other, the gender identity that the poet frequently invokes in her poems. In this sense, Doubiago seems to universalize the theme of her gender identity when she addresses her daughter in a didactic way, using phrases such as "universal culture of sexism," "reactionary psychology," "core relationship," and "masculine imbalance." This tone of didactic discourse draws Ullman's attention, noticing that the resulting "diffusion of consciousness" of the poet is obvious in most of her poems, allowing her to diversify and interweave her gender motifs and themes (I993, p. 195).

We see the mythical and the personal references fused into one multi-layered ballad of South America Mi Hija. In another place, Doubiago searches for suitable words to frame her gender identity and subjectivity as the self against the male gender identity as the other. Her words represent a means of explaining and preventing the tragedies of her gender identity in an influential mythopoetic way. -For her, this process is the mechanism in which men "deny their mothers... to find/themselves/ to develop/ technology/ to make/ war" (I992, p. 95). Meanwhile, Ostriker views different stances where Doubiago celebrates "a marriage of opposites" (200I, p. 258). It is the continuous gender conflict, as we will see. In addition, the poet notices that women deny "the feminine" in themselves to keep their fathers. The poet directs her quest in mythic terms linking her journey with Persephone's abduction "into the abyss" after being raped by Pluto. Doubiago portrays South America like Persephone, who represents her daughter suffering under patriarchy, "The Third World/ screams, it drops/ it pisses, it hisses, it/ sinks" (I992, p. I00)

Doubiago embraces the whole landscape of South America and identifies it with her "self and her daughter embodying the promise of the future in which the "gender balance/ of nature" will be resorted. In this regard, Doubiago's mastery of universal mythologies allows her to find universal significance and objective correlative for her personal stress. Such mythopoetics makes our understanding of the poet's psychosexual equations easier, she admits that "all patriarchies/long for the father" who are the females' source of pleasure and prosperity.

However, Doubiago, armed with numerous mythical images and signifiers of Aphrodite and Demeter, keeps questing for the self, creating a kind of "revolution of the human beyond gender identity." Doubiago plainly intensifies the moment of being identified in gender where "each woman is a new goddess/from which each man launched a new war/ the war of gender" (Ibid 230). In this poetic context, the self is hidden in the psyche of the individuals, and it appears only in their inner world. The quest for the self-engages Doubiago's mind to locate the meaning of her gender identity and publicize it. In this sense, Howe gives another definition of the self, "a construct of mind, a hypothesis of being, so socially formed" (I992, p. 249).

South America Mi Hija is characterized by the use of a set of binary oppositions and differences, such as the conflict between stasis and dynamic mobility, isolation and engagement, where the poetess touches her daughter's "powerful flesh" and realizes that all civilizations have fallen down because of the terror of "flesh, women, nature, death, Eros, soul, the unknown, the unnamed, the unsaved inconsequential self." It is the tensest moment of the whole collection when the poet refers to things that stand in the way of the possibility of rebirth for the self. While in the early poems the self is imaged in terms of its own possibilities of transformation, where "men are unable to love in the universal culture of sexism! deeper, more ingrained than racism" (Doubiago, 1992, p. I4), in the later poems like "Psyche," the self is more often seen as trapped within a closed cycle where the "Psyche will hide from even the self... in her cocoon/on her butterfly wings" (Ibid, p. 26I). The poet moves in a circular space back and forth, but she seems to move more often towards the starting point where her identity can be more sustained and recognized and her psyche "travels/ life after life my life, station! After station to be tried" (Ibid, p. 38).

Doubiago's poems record the self in the world where this self -as a female figure- can change, develop, transform, and be reborn. These possibilities of the self are intimately and inextricably bound up with those possibilities of the world where the "feminine part of Earth" is motivated by feelings of distinguished identity and belonging. These mature, distinguished qualities enable the poet to stand on the opposite space of the male as the other. Besides, the poetic discourse that the poet follows shows us that the other should be understood according to the "spiritual discipline," which, I think, privileges the male authority as the only dominant power in the society. For Doubiago, this discipline engenders "self-betrayal" and "self-hatred" on the part of the females, where women know "complicity/at the core of the self/ with the patriarchy" (Ibid, p. 266). In these words, there is a confession that women take roles in engendering such equation of male-female relationship and submit peacefully-- or by intimidation-- to the other gender. This notion of submission of the self to the other is clear when the poet touches the stone and sees "Isis/still searching for the phallus/through patriarchies of all times all places" (Ibid, p. II). 
Doubiago's metaphoric signs of fragmentation and reification-- the abstraction of the self as an individual--are based on social, political, cultural, and historical facts. Such signs and allusions include the myths of Demeter and Persephone, Third World countries, Buddhism, Confucianism, the Sidewinder, Adam and Eve, and masochism. Other images that denote such metaphors include "culture's altar," "Marx," "Earth," and "Nature." It is Doubiago's consciousness of the other, the man, in terms of gender conflict and identity. According to the poet, the man in the poem is finally defined by carrying both "the male and the female/ in his genital sacks." But the definition of the women shows her even more alienated, objectified, and dehumanized. While the $\mathrm{man} / \mathrm{male}$ is the masculine figure who longs for woman to "find the answer/ the riddle of the Sphinx," the woman is the "feminine part of the earth" who should revolt and be motivated by feelings of love. Thus, women do not exist in the gender space unless men need and will them to. This notion of masculinity and femininity reflects the poet's awareness of gender imbalance and the pains it causes to her gender in a dominant masculine milieu. She addresses her daughter, "O girl/we are the lost feminine/the world searches for/the feminine/the world dies for" (Ibid, p. 94). Here, there is a hint to social and cultural injustices that deny women's right to be reborn, empowered, and recognized as an inextricable half in society. So, the poet declares a revolution against such injustices telling us that her question is "To be / or not to be," because her culture hates women and the feminine, and this is unfair and "stupid." These significances reflect the poet's dual consciousness of the self as both subject and object. As a result, Doubiago shows the characteristics of the literature of the oppressed classes in society.

South America Mi Hija, as a feminist epic lengthy poem, is vivid and dynamic; it moves from one space into another in a persuasive way so that we can understand that the poetess means to raise questions about her freedom of action, opinion as long as "Poetry depends on intellectual freedom" (Woolf, I989, p. 17). In this sense, Ellison says that such dual consciousness is characteristic of "revolutionary" literature, since it shows the "dialectical perception" of self as both subject and object (I990, p. I32). Yet, does this dialectical consciousness of the self as object and subject reflect the poet's particular social context? I think the poet seems unable to develop a consciousness of herself in relation to other women. There is no collective identity and discourse; instead, it is a subjective feminine discourse despite the many personas and objective correlatives she creates. This poetic device raises the question of how one woman can account objectively for herself and other women in terms of gender war and the injustices they encounter in society. In this regard, can the poet also be objective and factual in her perception, free from myths and personas? I think she does not show much of her objectivity in this poem, rather it is the dominant subjectivity that directs her discourse. In a poem like "Mamapacha the Loving Mother of Men," there is a suppressed hysteria where the poet mixes surrealism, objectivity, and subjectivity. The images of the poem are predominating images of civil war, betrayal, earthquakes, race, and bleeding:

The earth quakes and the people float<smiles>[CH]1CNC1</smiles>

watch out, the Indian warned me, for those men

with knives

the people cry, parade in the Square of Weeping

their black Jesus, Lord of the earthquakes.

(Doubiago, 1992, p. 196)

Then she shifts her poetic discourse to a new scene of her own images of hemorrhage where her blood was "pouring out of my vaginala hemorrhage can't stop/ the blood of a lost civilization, a flood," the blood that comes from inside woman, any woman (Ibid, p. 197). These images suggest the poet's emotional dissociation from the horrific images of killing and dying to the terrible detail of the hemorrhage image. These images also signify the poet's sense of depersonalization, the splitting of herself on one hand, and the separation of society from itself. I think such dissociation reflects her worries about her gender identity and the ingratitude of her patriarchal society for women.

Throughout the poem and being trapped inside her subjective vision, the poet sees herself caught between nature and society, biology and intellect, Demeter and Persephone, Isis and Osiris, self-definition and the expectations of others, as between two mirrors. This image of mirror occupies a relevant space in the poet's discourse where she looks at herself, and she becomes blind exposing her inability to live her gender's problems and troubles. Seemingly, the closer the women come to Macchu Picchu, the deeper Doubiago focuses on herself, presenting her personal memories and other cultural motifs. She tells us that Macchu Picchu is a woman's city and "American city of Sapplo ... a nation! Of female warriors" (Ibid, p. 208). So, it is her self-awareness of womanhood that gives her the impetus to present herself and other women as vital partners in the game of "gender war." She is fully conscious of this war, where she plays her feminine roles that vary from "the rough banality of the divine" (Stimpson, 1993, p. 262). Hence, Doubiago witnesses and reports the pains, woes, helplessness, and sufferings of her gender. In this lengthy poem, the poet shows a large sense of self that enables her to remember and witness the tiny detail of feminine microcosm in the sphere of the large universe, "I'm broken so badly, I'm every creature/ever trapped in matter and thought, civilization/calcified as rock" (1992, p. 283). The self here is the poet's "lens of scrutiny" with which she investigates the psychological states of her gender, and it is helpful for the study of anxiety, the condition that grows in "acuteness" as awareness of self-increases (Howe, I992, p. 25I). Also, Lynch pinpoints that Doubiago masters the feminine discourse where she holds in a hand her gender identity 
and in the other her national identity; both are fused in her lengthy epic in South America Mi Hija, where she offers her readers imaginative poems full of metaphor, poems that "thrum with a pulsing feminine sensibility" (2000, p. 28I).

Moreover, gender is the central dominant theme of this poem, and it is sustained by the many allusions and references Doubiago mentions ranging from myths, heroes, heroines, nature, herself, and her daughter. This theme is the focus of the feminist discourse in literature nowadays. This discourse attempts to "integrate social and political determinations with an analysis of the psychic ordering of gender" (Ellison, 1990, p. 222). The poet's poetic moral revolves around the words "gender," "hegemony," and patriarchy that she inserts in her lengthy poem. Her feminist discourse is centered on her "womb" and "vaginal space" where she bears the microcosm of her gender:

$$
\begin{aligned}
& \text { I wait } \\
& \text { for the words to rise } \\
& \text { out of my rising flesh } \\
& \text { I can near the words } \\
& \text { babbling in the creek of my womb } \\
& \text { calling through vaginal space. (Doubiago, I992, p. 3I) }
\end{aligned}
$$

Here, Doubiago creates her own theory about the nature of the relations between sexes, which distinguishes females from males; and gender, which distinguishes the feminine from the masculine according to social and cultural roles (Tyson, I999, p.84). Doubiago is aware of the profound relation between sex and gender, and she knows that the bodies and sexualities of women and men are different. Her poetry in South America Mi Hija belongs to a feminist school that "universalizes, stabilizes, and carnalizes" the interplay between the two words: men and women. For the poet, sexuality means erotic desire, seduction, and gratification; besides, it is a means of procreation and generation. She mentions that men, our fathers, carry sperm that determine the sex of the infant. To the best of my knowledge, there are two kinds of sperm: the male that has short life span, twenty-four hours, and the female that has longer life span, up to seventy-two hours. This suggests that the poet is aware of this fact and sustains that females are capable of surviving hardships and troubles.

Therefore, Doubiago is aware of her feminist role in society, and this awareness is reflected in her thematic and rhetorical ways of her discourse. On the level of gender subjectivity and identity, femaleness unites women, while maleness unites men in the domain of heterosexuality. Mother, as the self in the gender war, occupies the main space of Doubiago's discourse. Also, she expresses her erotic feelings as a mother to her daughter passionately and didactically in "Earth Lagos Present:"

$$
\begin{aligned}
& \text {.. . entered a strange stream, a sexual } \\
& \text { stream, the ecstasy of time and place } \\
& \text { like mountain, like seas at the risen continents } \\
& \text { I could hear time, a mechanic sound } \\
& \text { I could feel creation, myself in place } \\
& \text { for the first time (Doubiago, I992, p. I27-28) }
\end{aligned}
$$

In this context, Ostriker views strong feminist discourse and consciousness about the common feminist issues in every society, implying that Doubiago's lengthy poem is characterized by "its amplitude and tempo," offering clear feminist views of the beauty and poverty, squalor, cruelty and mystery "out the window," all of which alternate with "inside" meditations on motherdaughter, mother-son, male-female love and betrayal--biological, psychic, mythic (200I, p. 260). Zhang views a wide and courageous step into "an aesthetic stream," whether "semantic" or "syntactic" (2004, p. I6).

Moreover, for Doubiago, the personal is the political, the religious, the cultural, and the universal. This is why South America Mi Hija seems to lament in detail the "interlocking of patriarchal psychology," when family structure, state, and faith are examined. Obviously, Doubiago uses the pronoun "I" numerously expressing a striking feature for her own self and subjectivity throughout the poem. In this regard, Meyers (2000) views the self as a subject of "enunciation," when the speaker uses the pronoun I. For Howe, the self "attains the dignity of a noun" to register an "enhancement of authority" (I992, p. 250). It is Doubiago's own way in referring to herself and her gender revealing her "sexed/gendered identity" freely and consciously.

No doubt, Doubiago's "historiography" tells us that women have neither accepted nor celebrated their bodies and sexuality, but they have imprisoned them in social, cultural, and psychological "cells" (Stimpson, I993, p. 266). Doubiago's feelings of misogyny are mentioned in different poems in her collection. She tells us that because some women have power, men have fought them, seduced them to objects and nothingness. In her poem "Mother," the poet touches the stone and knows the male, knowing his identity, "must see his mother/female/must objectify her/woman" (Doubiago, I992:265). Then she touches the stone and knows "the hatred of woman/is the hatred of nature" (Ibid 267. Also, she addresses her daughter in "Gender," telling her that male rejects "women/his mother and will identify himself... objectifying you/his first act of self (Ibid, p. 27I). 
Commenting on this issue, Ostriker tells us that Doubiago employs a convention that "the male-female conspiracy to keep history mad has become impossible to sustain" which is a recurrent and agonizing motif throughout South America Mi Hija (200I, p. 260).

For Doubiago, the war against women is civilization's war since women connect us to nature:

The flesh and blood from which we come Mama first Virgin Unknown. Unconquerable female body, maker of our death as well as our life, why her, why we hate Nature. (I992, p. 28I)

Such hatred of both women and nature and the destruction of civilization are man-made a pocalypse" (Stimpson, 1992:266). Doubiago's sight and insight see men write and act out patriarchal scripts, and rule women. They, men, also reduce female creativity to the figure of Isis, the goddess who must find and bind the fragments of a dismembered male body together: Earth will explode consciousness is a created creative event a bucket full of water as we are creating it We are not separate but psyche will hide from even the self (1992, p. 26I). This is why she chose to travel with her daughter, not with her son. The mother-daughter relationship is crucial to the identity of each one of them because". .. the daughter is the core of the mother." This relationship is based on giving birth to a daughter, mothers give rebirth to themselves. It is, I think, universal fact and tradition. Thematically, Doubiago also searches for the core of being, of framing her self, of defining her gender in the hegemonic patriarchal ideologies. She is aware of this system where all natural, human, and sacred activities are "organically' connected, establishing relations that "puns and words with double/treble meanings convey" (Stimpson, I993, p. 268). Woolf stresses that women and men are different in a variety of ways; their nerves that feed their brains are different. It is right whenever it comes to writing poetry or fiction for they have different genes, mentalities, capabilities, attitudes, social norms, habits, desires, hopes, expectations and dreams (1989, p. 99). Yet, Woolf cries to "Lock up your libraries ... [and] to set upon the freedom of ... mind," so she defies the patriarchal powers that enable men to be the superiors in any human society and calls women to decide upon their own paths (Ibid, p. III). Later, Doubiago hopes to revolt with other women to change the dominant structures of gender within the self, family, and society. This gender revolution will end with the collapse of all other structures of domination and submission. The poet also aspires to subvert the "male monopoly of positions of economic, political, and social power" (Tyson, I999, p. 84). This is ostensible in the poem "Amazon" where the poet admits hysterically the dominance of the male 'masculinity" over women femininity through the sufferings, hate, heartbreak, labor, and birth on the part of women. Doubiago, however, does not surrender to such a system; she calls for reclaiming the female powers that the "patriarchs have removed from the public life" (Stimpson, 1993, p. 70). She continues mentioning myths, legends, and feminine-nature images sustaining her popular consciousness in the arena of gender war. Replacing the refrain "out the window' with another one "I touch the stone," Doubiago emphasizes her gender unity against the patriarchal dominant society:

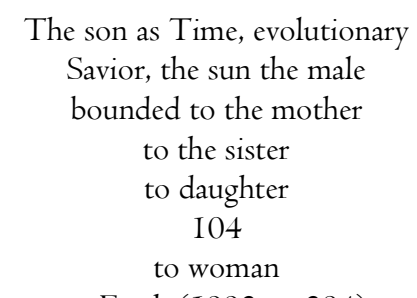

to Earth (1992, p. 284)

This replacement asserts Doubiago's feminist vision of female's originality and capability of always being the center of the creation in the world. In brief, Doubiago presents her self-discovery as a woman and a mother emphasizing her perspectives of the gendered self and other. She also shows self-awareness and consciousness of her gender war in the dominant patriarchal societies. Her gender themes about the self and the other are conveyed plainly and extensively. Yet, Woolf states that masculinehegemonic beliefs and practices challenged women creativeness and voices:

Since her pin money, which depended on the goodwill of her father, was only enough to keep her clothed, she was debarred from such alleviations as came even to Keats or Tennyson or Carlyle, all poor men, from a walking tour, a little journey to France, from the separate lodging which, even if it were miserable enough, sheltered them from the claims and tyrannies of their families. Such material difficulties were formidable; but much worse were the immaterial. The indifference of the world which Keats and Flaubert and other men of genius have found so hard to bear was in her case not indifference but hostility. (I989, p. 52)

This means that women have to challenge the rooted power of men in order to set up a place for their own creativity and voices. Women also have to decentralize the male authority to construct a unity for gender coherent self and authorial discourse. Woolf offers a cry to engender and strengthen feminist consciousness against the dominant masculine identity and authority. 


\section{References}

Doubiago, S. (1992). South America mi hija. Pittsburgh: University of Pittsburgh Press.

Eisler, R. (1987). The Chalice and the Blade. Our History, Our Future. London (Harper/Collins) 1987.

Ellison, J. (1990). Delicate subjects: Romanticism, Gender, and the Ethics of Understanding. Ithaca: Cornell UP.

Howe, I. (I992). The Self in Literature. The Construction of the Self. Ed. George Levine. Rutgers UP, 249-66.

Lewis, M. \& Brooks-Gunn, J. (1989). Social Cognition and the Acquisition of Self. New York: Plenum.

Lynch, D. (2000). Body and Soul. Library Journal. 125, 276-283.

Meyers, D. (2000). Self-Understanding and Theory of Mind. Stanford Encyclopedia of Philosophy. Retrieved August 30,2019 from http://Plato.standford.edu/entries/feminism-self/\#A.

Ostriker, A. (200I). Beyond confession: The poetics of postmodern witness. The American Poetry Review, 30(2), 35-39.

Stimpson, C. R. (1993). Demeter in South America. Parnassus: Poetry in Review. I7/I8, 258-7I.

Tyson, L. (1999). Critical Theory Today: A User-Friendly Guide. New York: Garland Publishing, Inc.

Ullman, L. (1993). Betrayal and Boundaries: A Question of Balance. Kenyon Review. I5, I82-96.

Woolf, V. (1989). A Room of One's Own. New York: Harcourt Brace.

Zhang, J. H. (2004). The Invention of a Discourse: Women's Poetry. Leiden: CNWS Publications.

\section{Copyrights}

Copyright for this article is retained by the author(s), with first publication rights granted to the journal. This is an open-access article distributed under the terms and conditions of the Creative Commons Attribution license (http://creativecommons.org/licenses/by/4.0/). 